\title{
REVIEW
}

\section{Sexual reproduction in octocorals}

\author{
Samuel E. Kahng ${ }^{1, *}$, Yehuda Benayahu ${ }^{2}$, Howard R. Lasker ${ }^{3}$ \\ ${ }^{1}$ Hawaii Pacific University, College of Natural Science, Waimanalo, Hawaii 96795, USA \\ ${ }^{2}$ Department of Zoology, George S. Wise Faculty of Life Sciences, Tel Aviv University, Ramat Aviv, Tel Aviv 69978, Israel \\ ${ }^{3}$ Department of Geology and Graduate Program in Evolution, Ecology and Behavior, University at Buffalo, Buffalo, \\ New York 14260, USA
}

\begin{abstract}
For octocorals, sexual reproductive processes are fundamental to maintaining populations and influencing macroevolutionary processes. While ecological data on octocorals have lagged behind their scleractinian counterparts, the proliferation of reproductive studies in recent years now enables comparisons between these important anthozoan taxa. Here we review the systematic and biogeographic patterns of reproductive biology within Octocorallia from 182 species across 25 families and 79 genera. As in scleractinians, sexuality in octocorals appears to be highly conserved. However, gonochorism $(89 \%)$ in octocorals predominates, and hermaphroditism is relatively rare, in stark contrast to scleractinians. Mode of reproduction is relatively plastic and evenly split between broadcast spawning ( $49 \%$ ) and the 2 forms of brooding (internal $40 \%$ and external $11 \%$ ). External surface brooding which appears to be absent in scleractinians may represent an intermediate strategy to broadcast spawning and internal brooding and may be enabled by chemical defenses. Octocorals tend to have large oocytes, but size bears no statistically significant relationship to sexuality, mode of reproduction, or polyp fecundity. Oocyte size is significantly associated with subclade suggesting evolutionary conservatism, and zooxanthellate species have significantly larger oocytes than azooxanthellate species. Based on biogeographic patterns, reef scleractinians appear to disperse longer distances over ecological timescales compared to reef octocorals. However, differences in reproductive characteristics between the 2 taxa do not offer an obvious explanation for these different biogeographic patterns.
\end{abstract}

KEY WORDS: Octocoral $\cdot$ Sexual reproduction $\cdot$ Coral reef $\cdot$ Life history $\cdot$ Biogeography

\section{INTRODUCTION}

Octocorals are a diverse and widespread group of marine organisms ranging across all latitudes and across depths from the intertidal zone to abyssal plains (Bayer 1981). The class Octocorallia has $\sim 310$ genera distributed among 3 orders: Helioporacea, Alcyonacea, and Pennatulacea (Bayer 1981). However, based on molecular data, McFadden et al. (2006) suggested that the orders are polyphyletic and that most octocoral taxa are members of 2 clades with a few taxa belonging to a much smaller third clade. Approximately 274 of the genera belong to the most speciose order, Alcyonacea, and some genera are very speciose including the Indo-Pacific coral reef genus Sinularia which has over 150 species (McFadden et al. 2009). Species of Alcyonacea include forms commonly known as soft corals, sea fans, and sea whips, and this order generally corresponds to the Alcyoniina/ Holoxonia clade hypothesized by McFadden et al. (2006). 
In many coral reef ecosystems, particularly in the Caribbean and some Indo-West Pacific reefs, shallowwater octocorals are a major, sometimes dominant, faunistic component (Bayer 1981, Benayahu \& Loya 1981, Dinesen 1983, Sammarco \& Coll 1992, Spalding et al. 2001). Among reef octocorals, the majority of species are zooxanthellate, possessing endosymbiotic microalgae in their tissues. However, many IndoPacific and some Caribbean reef species are azooxanthellate (Fabricius \& Alderslade 2001). In deep-water ecosystems, octocorals are important structure-forming organisms that colonize substrata in dense aggregations and create critical habitat for associated fauna (Lumsden et al. 2007, Messing et al. 2008).

Like many species of Anthozoa, octocorals are almost exclusively modular colonial marine invertebrates that reproduce both sexually and asexually. As in all modular organisms, colony growth is a mode of asexual reproduction via budding of polyps. In addition, octocorals exhibit a diversity of mechanisms of vegetative propagation including simple fission, fission by partial mortality, fragmentation, polyp detachment, budding, branching growth, and stolonal growth (Lasker 1988). For some species, asexual, vegetative propagation can support high population growth rates (Lasker 1988). All octocorals that have been studied in detail reproduce sexually. The dual modes of reproduction allow species to follow multiple ecological strategies (Jackson 1985). However, sexual reproduction remains the dominant mode of population growth for most species. Sexual reproduction and the dispersal of the resultant larval stage control the connectivity of populations and maintains the genetic diversity in octocorals as in all benthic invertebrates (Jackson 1986).

Until the early 1970s, most of the knowledge on the reproduction of octocorals had been based on studies of a small number of species. Some of the earliest studies characterized reproduction in the widespread boreal species Alcyonium digitatum (e.g. de Lacaze-Duthiers 1864, Hickson 1895, 1901, Hill \& Oxon 1905, Matthews 1917). The pioneering study of Kowalewsky \& Marion (1883) examined the embryogenesis of Clavularia crassa, C. petricola and Sympodium coralloides and depicted detailed images of planula-development. Gohar (1940a,b) and Gohar \& Roushdy (1961) provided valuable information on reproduction of the Red Sea soft corals from the family Xeniidae.

A growing number of reproductive studies of octocorals have been undertaken in recent years, but the reproductive patterns of octocorals have never been comprehensively reviewed. In contrast, the repro- ductive patterns of stony corals (Scleractinia) have been the center of intense study in recent decades (Fadlallah 1983, Szmant 1986, Harrison \& Wallace 1990, Richmond \& Hunter 1990, Richmond 1997, Shlesinger et al. 1998, Baird et al. 2009, Harrison 2011). Given the abundance of both scleractinians and octocorals in tropical reef ecosystems and the ecological similarities between them, a thorough compilation of the available octocoral data and comparison of their reproductive strategies with those of scleractinians can indicate whether reproductive strategies in the 2 groups have paralleled each other.

\section{METHODS}

The octocoral reproductive traits considered in the analyses are listed in Table 1. Data were gathered through an exhaustive search of the literature, communication with other researchers, and our own unpublished data. However, as apparent from Table S1 (see electronic supplement, available at www.intres.com/articles/suppl/m443p265_supp.pdf, obtaining complete information for many of the species was not possible. However, basic information such as sexuality and the modes of larval development were available for the vast majority of species.

\section{Systematics}

Among octocorals, morphological characters have been traditionally used to distinguish between taxa. These particularly include colony growth form, axial structure, and the size, shape, micro-architecture, and arrangement of sclerites (e.g. Bayer 1961, Berntson et al. 2001, Alderslade 2001, Fabricius \& Alderslade 2001). Attempts to understand their phylogenetic relationships have been hampered by a paucity of useful morphological characters and consequently led to molecular phylogenetic analysis of this group. McFadden et al. (2006) presented mitochondrial DNA (mtDNA) analyses that convincingly argued that most of the currently recognized families and suborders in the Octocorallia are polyphyletic. However, a revision of the higher taxa has not yet been made. In our treatment we continue to refer to the traditionally recognized families since most readers are familiar with them (see also Fabricius \& Alderslade 2001). Although there are some important inconsistencies, they do have a general congruence to the patterns reported in McFadden et al. (2006). However, in our statistical analyses we use Clades 1,2 and 3 as recognized by 
Table 1. Reproductive traits and other factors considered for each octocoral species in this study

\begin{tabular}{|c|c|}
\hline Characteristic & Description \\
\hline \multicolumn{2}{|l|}{ Reproductive traits } \\
\hline Sexuality & $\begin{array}{l}\text { Species are classified as either gonochoric; gonochoric with rare }(<1 \%) \text { hermaphroditism; } \\
\text { mixed sexuality with a regular incidence }(>1 \%) \text { of male, female, and hermaphroditic colonies; } \\
\text { hermaphroditic; or parthenogenic }\end{array}$ \\
\hline Sex ratio & For gonochoric species, the ratio of female to male colonies \\
\hline Mode of reproduction & $\begin{array}{l}\text { Species are classified as either a broadcast spawner; internal brooder; or an external surface } \\
\text { brooder }\end{array}$ \\
\hline Maximum oocyte size & The maximum oocyte size in terms of diameter, measured in $\mu \mathrm{m}$ \\
\hline Length of oogenic cycle & $\begin{array}{l}\text { Number of months required for completion of } 1 \text { oogenic cycle. Species with multiple concur- } \\
\text { rent oogenic cycles and where length of a single cycle cannot be determined are classified } \\
\text { accordingly }\end{array}$ \\
\hline Polyp fecundity & Average number of mature oocytes per polyp \\
\hline Breeding period & Number of months when spawning or brooding occurs per year \\
\hline \multicolumn{2}{|l|}{ Other factors } \\
\hline Clade/Subclade & Based on McFadden et al. (2006). See manuscript text for explanation \\
\hline Subclade $_{\text {cons }}$ & Modified from McFadden et al. (2006). See manuscript text for explanation \\
\hline Symbiont status & Species are classified as either zooxanthellate or azooxanthellate \\
\hline Latitude & $\begin{array}{l}\text { Latitude of sampling locations used in reproductive study or studies. Where sampling locations } \\
\text { span a range of latitudes, the midpoint was selected }\end{array}$ \\
\hline Climate/Habitat & $\begin{array}{l}\text { Species are classified according to the primary location where the reproductive data origi- } \\
\text { nated: tropical where annual mean sea surface temperature (SST) }>25^{\circ} \mathrm{C} \text { (trop); subtropical } \\
\text { where annual mean SST }=22-25^{\circ} \mathrm{C} \text { (subtrop); temperate where annual mean SST }<22^{\circ} \mathrm{C} \text { and } \\
\text { annual max SST }>15^{\circ} \mathrm{C} \text {; and cold or deep where annual maximum in situ temperature }<15^{\circ} \mathrm{C} \text {. } \\
\text { These groups were further aggregated as warm (tropical and subtropical) and cool (temperate } \\
\text { and cold/deep) for certain analyses }\end{array}$ \\
\hline
\end{tabular}

McFadden et al. (2006). We also divided the taxa into subclades based on the parsimony analysis presented in Fig. 1 in McFadden et al. (2006) and those designations are listed in Table S1. Although there are some differences, those subclades are generally concordant with those inferred from either the Bayesian or maximum likelihood analyses that McFadden et al. (2006) also conducted (their Figs. 1 \& 2). Subclade assignments were made twice: the assignments in Table S1, and a somewhat more conservative classification $\left(\right.$ Subclade $\left._{\text {cons }}\right)$ in which genera not included in the McFadden et al. (2006) study were dropped from the analysis. With only minor exception the 2 systems generated the same results and only the original subclade analysis is presented. Given the need for greater taxonomic coverage and more molecular markers, future refinement of these phylogenetic hypotheses is likely. The use of the phylogenetic hypothesis proposed by McFadden et al. (2006) is important in considerations of the evolution of traits within the Octocorallia. In considering transitions between character states, we mapped traits on the McFadden et al. (2006) phylogram, assuming that none of the genera are polyphyletic.

\section{Statistical analyses}

Patterns in the data were tested using log-linear analyses (SPSS, version 17.0) in which the independence of taxonomic group, climate or habitat, presence or absence of zooxanthellae, sexuality and mode of gamete or larva release were determined. In general, large multi-way log-linear tests provide the means to separate the effects of correlations among character states. Given the large number of characters and character states, a complete test of independence led to a matrix with many cells having predicted values of $<5$, which dramatically reduces the power of the analysis. In order to minimize that effect, categories were often pooled or dropped from the analysis. Pooled categories for subclade are indicated in Table 2. Mode of reproduction was reduced to broadcast spawning, and brooding and climate was reduced by pooling deep/cold with temperate and subtropical with tropical. Even with pooled categories expected values when more than 2 factors were considered were often below 5, and many of the results were further tested with 2-way tests of independence based on $\chi^{2}$ 
Table 2. Distribution of studies and reproductive data across (A) groups, families and climate and (B) clades, subclades and climate

\begin{tabular}{|c|c|c|c|c|c|c|}
\hline \multirow{2}{*}{ (A) Group } & \multirow{2}{*}{ Family } & \multicolumn{4}{|c|}{ Climate } & \multirow{2}{*}{ Total } \\
\hline & & $\begin{array}{l}\text { Deep or } \\
\text { cold }\end{array}$ & $\begin{array}{l}\text { Tem- } \\
\text { perate }\end{array}$ & $\begin{array}{c}\text { Sub- } \\
\text { tropical }\end{array}$ & $\begin{array}{l}\text { Tro- } \\
\text { pical }\end{array}$ & \\
\hline \multirow[t]{3}{*}{ Alcyoniina } & Alcyoniidae & 2 & 15 & 11 & 32 & 60 \\
\hline & Nephtheidae & 3 & 6 & 6 & 0 & 15 \\
\hline & Xeniidae & 0 & 0 & 24 & 7 & 31 \\
\hline \multirow[t]{4}{*}{ Calcaxonia } & Chrysogorgiidae & 1 & 0 & 0 & 0 & 1 \\
\hline & Ellisellidae & 0 & 0 & 1 & 2 & 3 \\
\hline & Isididae & 4 & 0 & 0 & 0 & 4 \\
\hline & Primnoidae & 12 & 0 & 0 & 0 & 12 \\
\hline Helioporacea & Helioporidae & 0 & 0 & 0 & 2 & 2 \\
\hline \multirow[t]{2}{*}{ Holaxonia } & Gorgoniidae & 0 & 0 & 2 & 6 & 8 \\
\hline & Plexauridae & 1 & 6 & 1 & 12 & 20 \\
\hline \multirow[t]{8}{*}{ Pennatulacea } & Anthoptilidae & 1 & 0 & 0 & 0 & 1 \\
\hline & Funiculinidae & 1 & 0 & 0 & 0 & 1 \\
\hline & Kophobelemnidae & e 1 & 0 & 0 & 0 & 1 \\
\hline & Pennatulidae & 1 & 3 & 0 & 1 & 5 \\
\hline & Renillidae & 0 & 2 & 0 & 0 & 2 \\
\hline & Umbellulidae & 2 & 0 & 0 & 0 & 2 \\
\hline & Veretillidae & 0 & 0 & 3 & 1 & 4 \\
\hline & Virgulariidae & 0 & 1 & 0 & 1 & 2 \\
\hline \multirow[t]{5}{*}{ Scleraxonia } & Anthothelidae & 0 & 1 & 0 & 0 & 1 \\
\hline & Briareidae & 0 & 0 & 0 & 4 & 4 \\
\hline & Coralliidae & 2 & 1 & 0 & 0 & 3 \\
\hline & Melithaeidae & 0 & 0 & 3 & 0 & 3 \\
\hline & Subergorgiidae & 0 & 0 & 0 & 2 & 2 \\
\hline \multirow[t]{2}{*}{ Stolonifera } & Clavulariidae & 0 & 1 & 0 & 5 & 6 \\
\hline & Cornulariidae & 0 & 0 & 2 & 0 & 2 \\
\hline \multirow[t]{2}{*}{ (B) Clade } & \multirow[t]{2}{*}{ Subclade } & \multicolumn{4}{|c|}{ Climate } & Total \\
\hline & & $\begin{array}{l}\text { Deep or } \\
\text { cold }\end{array}$ & $\begin{array}{l}\text { Tem- } \\
\text { perate }\end{array}$ & $\begin{array}{l}\text { Sub- } \\
\text { tropical }\end{array}$ & $\begin{array}{l}\text { Tro- } \\
\text { pical }\end{array}$ & \\
\hline \multirow[t]{10}{*}{1} & $1 \mathrm{a}$ & 0 & 4 & 0 & 8 & 12 \\
\hline & $1 b$ & 0 & 0 & 25 & 8 & 33 \\
\hline & $1 \mathrm{c}$ & 0 & 6 & 5 & 2 & 13 \\
\hline & $1 d$ & 0 & 0 & 1 & 6 & 7 \\
\hline & $1 \mathrm{e}$ & 1 & 3 & 0 & 2 & 6 \\
\hline & $1 \mathrm{f}$ & 0 & 0 & 2 & 6 & 8 \\
\hline & $1 \mathrm{~g}$ & 0 & 0 & 8 & 26 & 34 \\
\hline & $1 \mathrm{~h}$ & 2 & 13 & 0 & 0 & 15 \\
\hline & $1 \mathrm{i}$ & 0 & 0 & 3 & 0 & 3 \\
\hline & $1 \mathrm{j}$ & 0 & 0 & 0 & 3 & 3 \\
\hline \multirow{3}{*}{$\begin{array}{l}\text { Clade } 1 \text { total } \\
2\end{array}$} & & 3 & 26 & 44 & 61 & 134 \\
\hline & $2 \mathrm{a}$ & 14 & 1 & 1 & 5 & 21 \\
\hline & $2 b$ & 7 & 5 & 3 & 2 & 17 \\
\hline Clade 2 total & & 21 & 6 & 4 & 7 & 38 \\
\hline 3 & & 3 & 1 & 0 & 0 & 4 \\
\hline
\end{tabular}

\section{RESULTS}

\section{Distribution of studies}

Bayer (1980) noted that the knowledge of octocoral biology lagged behind systematics. Early anatomical works by naturalists from scientific expeditions in the 19th and 20th centuries (e.g. Challenger, Albatross, Danish Ingolf, Siboga, Charcot, and Canadian Arctic expeditions) provide basic reproductive information (i.e. sexuality and evidence of larval brooding) on numerous species based on examinations of dredge samples. These often overlooked historical descriptions remain a primary source of published information for many deep-water octocoral species. However, with the overall growth in coral reef research providing data on coral reef species and the recent focuses on mesophotic and deep water habitats, there have now been sufficient studies to support an overview of octocoral reproductive biology (Lumsden et al. 2007, Hinderstein et al. 2010).

The distribution patterns of octocoral taxa constrain the data and their analysis. In the Caribbean-Atlantic, $85 \%$ of the tropical shallow-water (defined as <50 m) species (196 species) are sea fans and sea whips, predominantly from the families Gorgoniidae and Plexauriidae. There are only 3 species from the subordinal group Alcyoniina and a handful of species from the group Stolonifera (Bayer 1961). In contrast, in the IndoPacific only $59 \%$ of the tropical shallow-water octocoral species (445 species) are sea fans and sea whips and Indo-Pacific habitats host a substantial diversity of fleshy soft corals, particularly in the suborder Alcyoniina in the families Alcyoniidae, Nephtheidae, and Xeniidae (Bayer (SPSS, version 17.0) or Fisher's exact tests ( $\mathrm{R}$, version 2.9.1). Oocyte sizes and fecundity were analyzed with analysis of variance and/or Kruskal-Wallis tests (SPSS, version 16).
1961, Sammarco \& Coll 1992, Fabricius \& Alderslade 2001). In general, there is little overlap between Indo-Pacific and Western Atlantic octocoral taxa (Sammarco \& Coll 1992), and with the possible 
exception of Cairjoa riisei (see Concepcion et al. 2010) no shallow-water, tropical species within Alcyonacea are known to naturally occur in both regions ( $\mathrm{P}$. Alderslade pers. comm.). The same is true of tropical species of scleractinian corals (Paulay 1997).

Deep-water coral ecosystems are often dominated by branching octocoral taxa (e.g. Coralliidae, Paragorgiidae, Chrysogorgiidae, Isididae, and Primnoidae) particularly in the North Pacific where the shallow calcium carbonate compensation depth may limit the depth distribution of scleractinians (Guinotte et al. 2006, Lumsden et al. 2007). In general, octocorals are much less calcified than scleractinians and secrete a more stable mineral form of calcium carbonate, i.e. calcite instead of aragonite. Pennatulaceans, sea pens, are characteristic members of deep-sea communities but several species also colonize shallow-waters at high latitudes. Sea pens are distributed across the world's oceans, and being uniquely adapted to soft sediment habitat, they form dense groves in many locations (Lumsden et al. 2007). In general, deep-water octocorals lack the well defined pattern of declining in biodiversity with increasing distance away from the centers of high biodiversity that shallow-water coral reef fauna exhibit (Bayer 1961, Grigg \& Bayer 1976, Paulay 1997, Veron 2000, Spalding et al. 2001) The presence of 2 distinct tropical faunas (CaribbeanAtlantic vs. Indo-Pacific) provides the opportunity to look for parallel patterns across habitats, but differences in the taxa represented across habitats and oceans confound habitat and historical effects.

The studies used in this review provided reproductive data on 182 octocoral species from 25 families and 79 genera: 164 species of Alcyonacea (soft corals, sea fans, and sea whips), 17 species of Pennatulacea (sea pens), and 1 species of Helioporacea (blue coral). Some species were studied in multiple regions and in some cases different patterns were found. As those could be cases of misidentification or cryptic species they were included in the analyses as independent cases. The vast majority of the species studied are from shallow, warm-water habitats, and not all taxonomic groups and biogeographic regions are equally represented. A majority of the reproductive studies on octocorals have focused on species from the subordinal group Alcyoniina (98 species) especially those from the Great Barrier Reef and Red Sea, and a moderate number of reproductive studies have focused on sea fans from the Caribbean and Mediterranean. In general, a paucity of reproductive data exists on species from other taxa and other regions. As already noted, the taxa studied to date are not evenly distributed across habitats (Fig. 1). Tropical and subtropical, usually reef habitats, are the most heavily represented habitat types (126 species), but as a consequence of both their distribution patterns and perhaps sampling, the higher taxa were not equally represented across the habitats $\left(\chi^{2}\right.$ test of independence: clade $\times$ habitat, $\mathrm{p}<0.001$; subclade $\times$ habitat, $\mathrm{p}<0.001$ ). Clade 1 taxa such as the plexaurids, xeniids, and alcyoniids are all overrepresented in warm-water communities, while Clade 2 and 3 taxa, such as pennatulids, primnoids and isiids, are most common in cold waters. An additional pattern in the subclade analysis was that of the clade containing Alcyonium having a primarily temperate distribution while xeniids and the clades containing Lobophytum, Sarcophyton and Sinularia are tropical or subtropical.

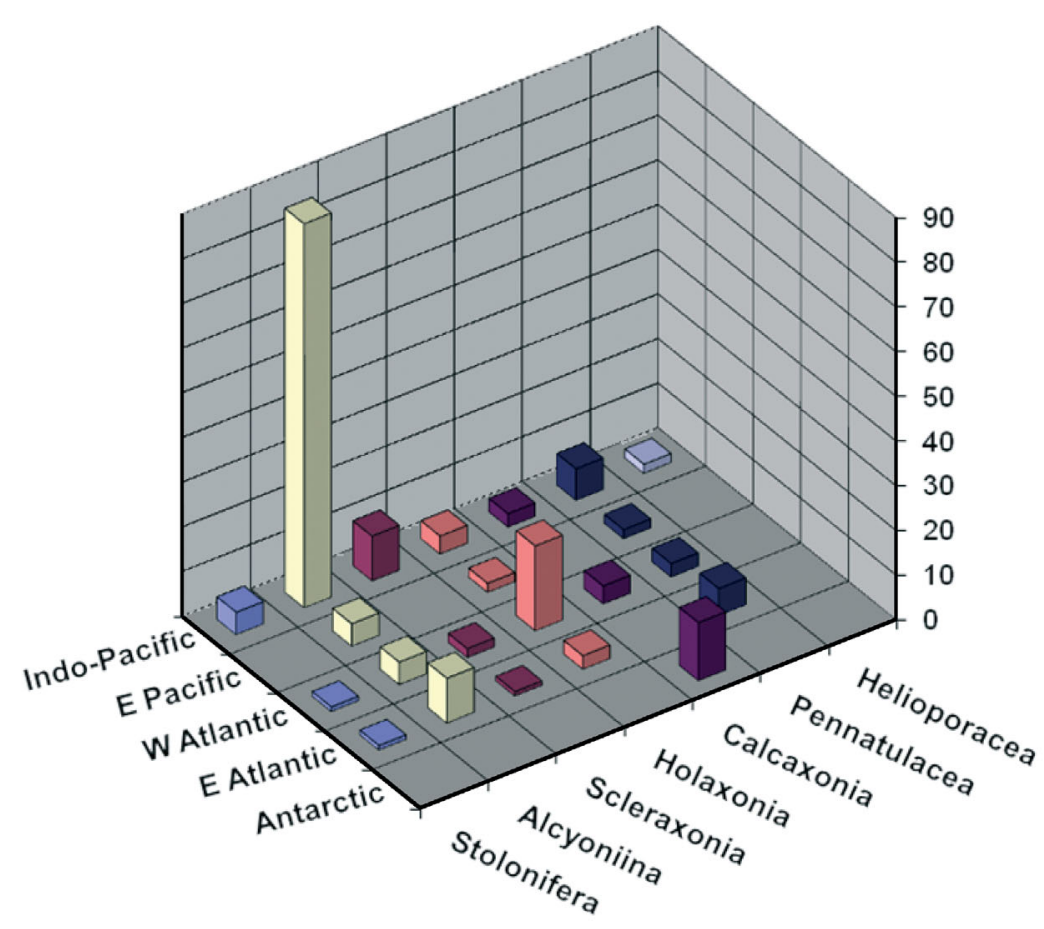

Fig. 1. Distribution of octocoral species where reproduction has been at least partially characterized by geographic region. Some species studied in more than 1 region $(n=194)$ 


\section{Sexuality}

As in all of the anthozoans, octocorals lack externally visible sexual features, and thus gonads provide the only guide to sexuality of the colonies (Hyman 1940). The earliest recognizable stages of octocoral gonads develop from endodermal cells in the mesoglea of the mesenteries (Farrant 1986). Subsequently, the gonads bulge into the gastrovascular cavities. The gonads develop on 4 lateral and 2 ventral mesenteries of the polyps and are mostly directed towards the center of the gastrovascular cavity (e.g. Benayahu \& Loya 1983). Each oocyte or sperm sac (spermary) is attached by a pedicle composed of a mesogleal core and surrounded by endoderm (Benayahu et al. 1992). The oocytes are enveloped by an inner mesogleal layer and an outer follicular endoderm, both continuous with the corresponding layers of the pedicle and the gastrovascular cavity.

In dimorphic octocoral genera, the gonads can be located in the siphonozooids (Bathyalcyon robustum: Bock 1938), in both siphonozooids and autozooids (Minabea robusta: Utinomi \& Imahara 1976), but commonly only in the autozooids (Lobophytum, Sarcophyton, and Heteroxenia: Yamazato et al. 1981, Benayahu \& Loya 1986, Achituv \& Benayahu 1990).

Octocoral species can be gonochoric in which mature colonies exclusively exhibit male or female reproductive tissue (i.e. gonads); simultaneous hermaphrodites in which both male (spermaries) and female (oocytes) gonads co-occur in the same colony; mixed having a regular incidence of gonochoric and hermaphroditic colonies; or parthenogenetic where oocytes produced by female colonies develop into viable planula larvae without fertilization.

The earliest reports of octocoral sexuality suggested that gonochorism is the dominant pattern among octocorals (Pratt 1903, Nutting 1912, Thorpe 1928, Hickson 1931), a pattern further supported in our compilation. Of 159 octocoral species with sexuality reported, $89 \%$ of the species are gonochoric and $9 \%$ are simultaneously hermaphroditic (Table 3). Two species (Sarcophyton glaucum from South Africa, Alcyonium coralloides from Western Europe) are reported as gonochoric but may be more accurately described as mixed - having a regular incidence $(>1 \%)$ of hermaphroditic colonies in addition to male and female colonies (de Lacaze-Duthiers 1900, McFadden 2001, Schleyer et al. 2004). Species that appear to have mixed reproductive patterns may reflect reports from more than one species. For instance, McFadden et al. (2006) report the presence of phylogenetically distinct clades within S. glaucum, which may represent a complex of cryptic species. Alcyonium hibernicum is the only octocoral species reported as being parthenogenetic, however, selfing hermaphroditism has not been ruled out (Hartnoll 1977).

In general, sexuality, and specifically gonochorism, appears to be a conserved trait with a low incidence of transitions to alternate states. Gonochorism and hermaphroditism were distributed evenly across clades and climates $\left(\chi^{2}\right.$ tests, $p=0.19$ and 0.18 respectively). A simple 2-way analysis of sexuality and subclade, with subclades pooled to meet assumptions of the $\chi^{2}$ analysis did not yield a significant result $(\mathrm{p}=0.08)$. However, log-linear analysis of sexuality, subclade and climate, with pooled groups, identified significant relationships between sexuality and subclade and with climate, whereby hermaphrodites were proportionately more abundant in 2 of the subclades as well as in cooler waters (Table 4A). The significant subclade effect can, however, be attributed to the presence of diversity in sexuality (both gonochoric and hermaphroditic species) in 7 genera (Acabaria, Alcyonium, Heteroxenia, Paramuricea, Sarcophyton, Sinularia and Xenia). These include most of the genera for which there are data for many species. When only the genera with data for more than 1 species are considered, sexuality was independent of genus (Fisher's exact test, $\mathrm{p}=0.250$ ). Alcyonium spp. had the greatest diversity of reproductive systems, but more extensive sampling across many additional taxa is necessary to determine whether this trait is associated with the genus or the subclade. When sexuality was mapped on the cladogram proposed by McFadden et al. (2006), each of the known transitions from gonochorism appears to have occurred at or within individual genera.

Two octocoral species exhibit different sexuality in different regions. Heteroxenia elizabethae is hermaphroditic in the Red Sea but gonochoric in the Great Barrier Reef (Gohar 1940a,b, Benayahu et al. 1990, Benayahu 1991). Sarcophyton glaucum is gonochoric in the Red Sea and Great Barrier Reef but mixed in South Africa (Benayahu \& Loya 1986, Alino \& Coll 1989, Schleyer et al. 2004). Given the difficulty in using morphological characteristics to taxonomically differentiate certain octocoral species (Sanchez et al. 2003), these reports of intra-specific variation in sexuality may reflect the presence of morphologically similar cryptic, sibling species. Any decisive conclusions concerning such intraspecific variation in sexuality will have to wait until a robust genus-level molecular phylogeny for numerous octocoral families as well as species- 


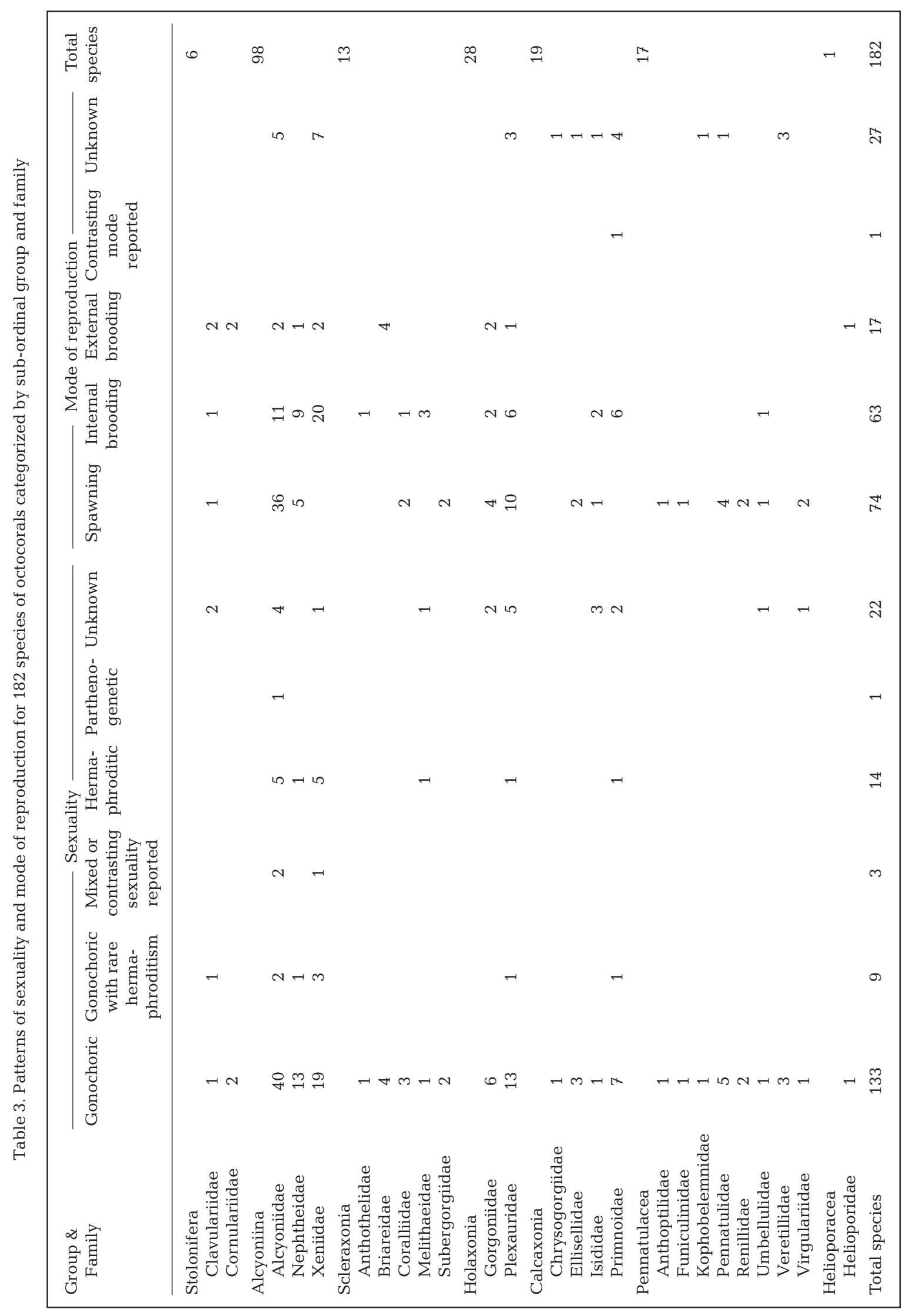


Table 4. Partial associations from log-linear analyses of the incidence of different reproductive features, habitats and taxonomic group. Groupings include sexuality (Sex), mode of reproduction (Reproduction), climate, and subclade. Only 2-way and greater partial associations are shown as the distribution within any single category only reflects sampling. Significant associations are noted in bold. The categories Climate and Subclade were pooled to minimize instances of expected values $<5$. Subclades were pooled in a manner to generate similar size groups while still maintaining integrity relative to the phylograms developed by McFadden et al. (2006)

\begin{tabular}{|lccc|}
\hline Effect & df & Partial $\chi^{2}$ & $\mathrm{p}$ \\
\hline (A) Sexuality, Subclade and Climate & \multicolumn{3}{l}{} \\
Sex $\times$ Subclade & 3 & 11.31 & $\mathbf{0 . 0 1}$ \\
Sex $\times$ Climate & 3 & 70.65 & $<\mathbf{0 . 0 0 1}$ \\
Climate $\times$ Subclade & 1 & 3.9 & $\mathbf{0 . 0 4 8}$ \\
(B) Subclade, Climate and Mode of Reproduction & & \\
Climate $\times$ Reproduction & 1 & 10.881 & $<\mathbf{0 . 0 0 0 5}$ \\
Climate $\times$ Subclade & 3 & 87.422 & $<\mathbf{0 . 0 0 0 5}$ \\
Reproduction $\times$ Subclade & 3 & 80.456 & $<\mathbf{0 . 0 0 0 5}$ \\
Climate $\times$ Reproduction $\times$ Subclade & 3 & 1.184 & 0.757 \\
(C) Climate, Sexuality, Mode of Reproduction & & \\
Reproduction $\times$ Climate & 1 & 3.741 & $\mathbf{0 . 0 5 3}$ \\
Reproduction $\times$ Sex & 1 & 7.224 & $\mathbf{0 . 0 0 7}$ \\
Climate $\times$ Sex & 1 & 0.347 & $\mathbf{0 . 5 5 6}$ \\
(D) Subclade, Sexuality and Mode of Reproduction & & \\
Sex $\times$ Reproduction & 1 & 8.09 & $\mathbf{0 . 0 0 4}$ \\
Sex $\times$ Subclade & 3 & 4.654 & 0.199 \\
Reproduction $\times$ Subclade & 3 & 76.596 & $\mathbf{0}$ \\
(E) Subclade, Climate, Sexuality and Mode of Reproduction & \\
Climate $\times$ Sex $\times$ Reproduction & 1 & 0 & 0.997 \\
Climate $\times$ Sex $\times$ Subclade & 3 & 0.019 & 0.999 \\
Climate $\times$ Reproduction $\times$ Subclade & 3 & 0.985 & 0.805 \\
Sex $\times$ Reproduction $\times$ Subclade & 3 & 0.509 & 0.917 \\
Climate $\times$ Sex & 1 & 0.195 & 0.659 \\
Climate $\times$ Reproduction & 1 & 5.431 & $\mathbf{0 . 0 2}$ \\
Sex $\times$ Reproduction & 1 & 6.852 & $\mathbf{0 . 0 0 9}$ \\
Climate $\times$ Subclade & 3 & 73.801 & $\mathbf{0}$ \\
Sex $\times$ Subclade & 3 & 4.518 & 0.211 \\
\hline
\end{tabular}

\section{Sex ratio}

Among the studies reporting sex ratios, a 1:1 female to male colony ratio, which is the optimal sex allocation in a population with random mating (Maynard-Smith 1978), was only reported in 26 of 56 cases (see Table $\mathrm{S} 1$ in the supplement). A female biased sex ratio is reported in 25 of 56 gonochoric octocoral species including 5 species where male colonies were reported as either absent or extremely rare (Brazeau 1989, Brazeau \& Lasker 1989, Vermeire 1994, Chou 2002, Yeung \& Ang 2008, Sun et al. 2009). A statistically significant male biased sex ratio has been reported in 4 octocoral species (Brazeau 1989, Vermeire 1994, Chou 2002, Yeung \& Ang 2008, Sun et al. 2010, Mercier \& Hamel 2011).

The surprising number of reports of female biased sex ratios is likely influenced by sampling bias. Determining the sex of an octocoral colony is generally accomplished from examination of histological sections or inspection of dissected tissue using a stereomicroscope, and when reproductive tissue is present distinguishing the 2 sexes is not difficult. Oocytes are commonly opaque compare to the more translucent spermaries, and in some species the dif-

level phylogenies for the most diverse genera are developed.

In the Octocorallia, simultaneous hermaphrodites exhibit both male and female gametes in the same polyp and on the same mesentery. In addition, there are reports of a low incidence $(<1 \%)$ of simultaneous hermaphroditism in 8 species that are otherwise gonochoric. Protandrous hermaphroditic development occurs in Heteroxenia fuscenscens where mature oocytes do not appear until the colony has achieved a minimum age or size (Achituv \& Benayahu 1990). Similar development has been implicated for Paramuricea placomus (Simpson 2005). Sequential hermaphroditism involving a complete reversal in colony sex (i.e. male to female or female to male) has not been observed in octocorals to date. However, this sexuality has recently been reported from scleractinian fungiids (Loya \& Sakai 2008, Loya et al. 2009). ference is further enhanced by color changes in mature oocytes e.g. Rhytisma fulvum fulvum, Sarcophyton glaucum and Briareum hamrum (Benayahu \& Loya 1983, 1986, Benayahu 1989, 1997). Sex can only be determined in colonies with discernible gonads, and octocoral oocytes tend to develop over a considerably longer period of time than required for spermatogenesis (Benayahu et al. 1990, Benayahu 1997). Consequently the identification of females is more likely over much of the year. In general, evaluation of reports of skewed sex ratios should also consider whether the sex of large numbers of colonies was indeterminate.

In species with prolific asexual reproduction and low recruitment of larvae produced through sexual reproduction, dominance by a few successful genets is possible (McFadden 1991, 1997) and can skew the sex ratio of a local population. Male colonies have 
been reported as either absent or extremely rare among Plexaura kuna, Junceella fragilis, and Sarcophyton trocheliphorum. However, these species reproduce asexually via fragmentation (Brazeau \& Lasker 1989, Vermeire 1994, Chou 2002), and asexual reproduction may have led to the apparent lack of male colonies. For instance, Brazeau \& Lasker (1989) failed to find males in an initial study of Plexaura kuna, a result that was generated by dominance at the site of several very large clones of female colonies (Coffroth \& Lasker, 1998).

Despite the general potential for bias in identifying females (due to prolonged gametogenesis), a significantly male biased sex ratio has been reported in Briareum asbestinum, Sarcothelia edmondsoni, Ovabunda macrospiculata, Capnella gaboensis, and Subergorgia mollis (Davis 1977, Benayahu \& Loya 1984, Farrant 1986, Brazeau \& Lasker 1990, Chang 2007). Male colonies tend to mature at an earlier age and smaller size than female colonies (e.g. Rhytisma fulvum fulvum, Sarcophyton glaucum, Dendronephthya hemprichi, and Briareum asbestinum) (Benayahu \& Loya 1983, 1986, Brazeau \& Lasker 1990, Dahan \& Benayahu 1997) making the identification of males more likely for small or young colonies among these species. In addition, a differential response to stress by sex has also been reported in the Mediterranean species Paramuricea clavata, in which partially damaged female colonies exhibited a greater reduction in the percentage of fertile polyps than similarly damaged male colonies following a period of high thermal stress (Linares et al. 2008).

\section{Mode of reproduction}

Three modes of reproduction have been described in octocorals: broadcast spawning during which colonies release gametes into the water column where external fertilization and planktonic embryonic development occur; internal brooding during which fertilization and embryogenesis occurs within the polyp resulting in the release of planula-larvae (i.e. vivaparity); and external surface brooding where eggs or zygotes are released by the polyps but retained on the colony surface where they then develop on ectodermal sites prior to release (Fig. 2) (Benayahu \& Loya 1983). Fertilization among surface brooding species may be internal prior to the release or external. Alcyonacean octocorals exhibit diverse brooding habits where the site of embryogenesis and brooding varies from the site of oocyte development and fertilization. Embryogenesis and brooding can occur in the gastrovascular cavity, non-gastrovascular cavities, pharyngeal cavities, ectodermlined inter-siphonozooid spaces, ectodermal brooding pouches, or the ectodermal surface of the parent colony within a mucus sheath (Benayahu 1997).

Of 152 octocoral species with modes of reproduction reported, $49 \%$ are broadcast spawners, $40 \%$ are internal brooders, and $11 \%$ are external surface brooders (Table 3). Reproductive mode in Octocorallia varied across clades and genera. Reproductive mode was independent of clade $\left(\chi^{2}\right.$ test, $\left.\mathrm{p}=0.56\right)$, but was not independent of subclade $\left(\chi^{2}\right.$ test of pooled subclade classes, $\mathrm{p}<0.0005$, Table 5). The speciose
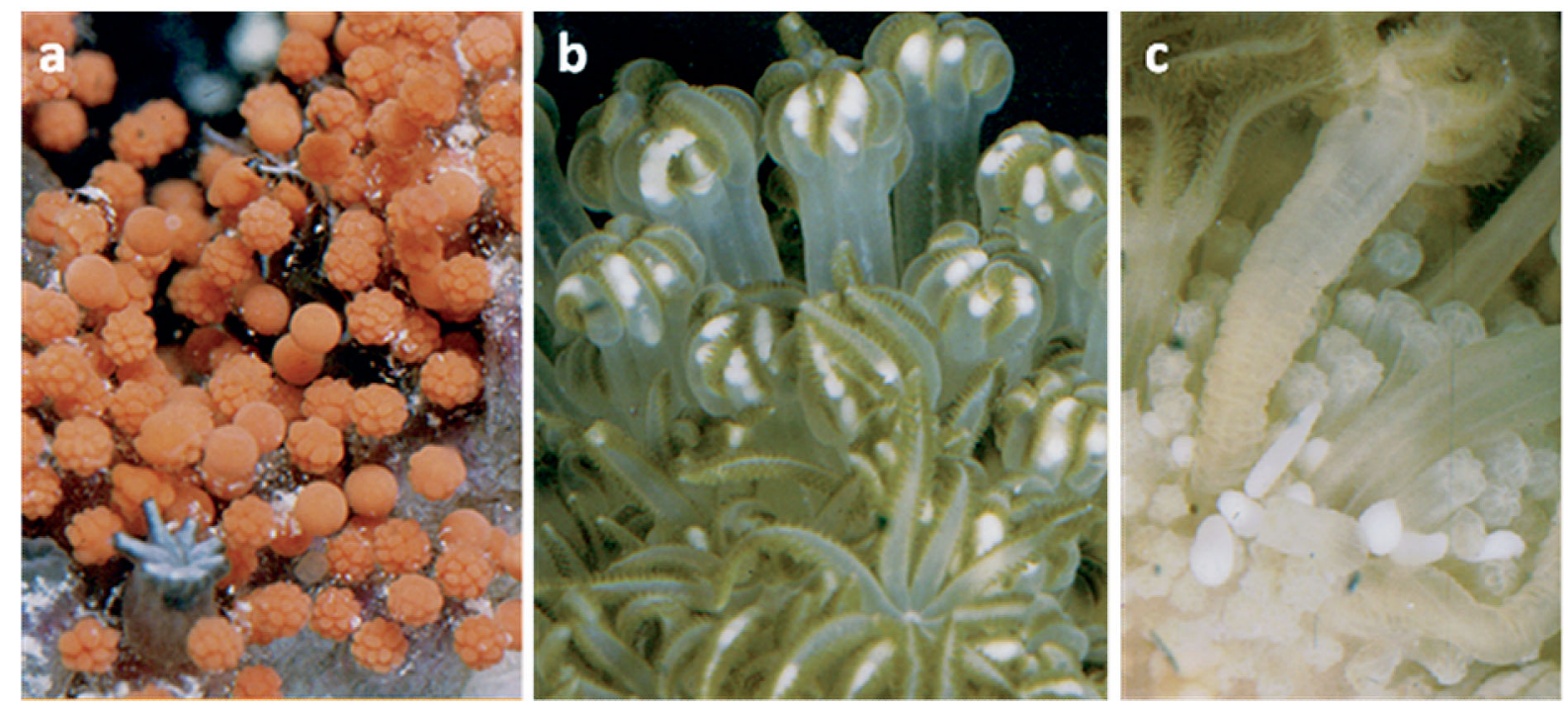

Fig. 2. (a) External surface brooding in Briareum hamrum, (b) internal brooding in Heteroxenia fuscescens, (c) release of planulae from inter-siphonozooid spaces in H. fuscescens. Photos courtesy of A. Shoob, Dept. of Zoology, Tel Aviv University 
alcyonacean genera Lobophytum, Sarcophyton, and Sinularia appear to be exclusively broadcast spawners. In contrast, broadcast spawning appears to be absent in the widely distributed families Xeniidae and the Primnoidae (but see Primnoa resedaeformis: Mercier \& Hamel 2011). All known sea pens (Pennatulacea), with the possible exception of Umbellula ecrinus (see Danielssen \& Koren 1884, Tyler et al. 1995) are broadcast spawners. Similarly, most species in the clade containing Caribbean plexaurid octocorals are broadcast spawners. The distribution of brooders and external brooders across the Octocorallia suggests that these modes evolved multiple times, a finding that McFadden (2001) has reported among Alcyonium spp. When analyzed as a 2-way contingency table, mode of reproduction was related to climate (Fisher's exact test, $\mathrm{p}=0.027$ ) with an excess of brooders in deep or cold habitats. This trend also correlated with the highly significant relationship between both clade and subclade with climate and the relationship between subclade and mode of reproduction. When climate, subclade, and mode of reproduction were considered in a log-linear analysis, the interactions between mode of reproduction and subclade was highly significant (Table 4B) However, there also was a highly significant mode of reproduction by climate interaction making it difficult to differentiate the causative relationship.

\section{Oocyte size}

While octocoral species exhibit a wide range of oocyte sizes at maturity, most produce relatively large oocytes (see Table S1). Of the 119 octocoral studies with oocyte size reported, the mean value for maximum diameter of mature oocytes is $686 \pm$ $253 \mu \mathrm{m}$ suggesting that octocoral propagules are well

Table 5. Mode of reproduction across subclades and climate. The dominant taxa in each pooled subclade are presented

\begin{tabular}{|lccc|}
\hline Subclade & Climate & Brood & $\begin{array}{c}\text { Broadcast } \\
\text { spawn }\end{array}$ \\
\hline Xeniidae & Cold & 0 & 0 \\
Lobophytum, Sarcophyton, & Cold & 0 & 0 \\
Sinularia & Warm & 0 & 34 \\
Other Clade 1 species & Cold & 20 & 9 \\
& Warm & 11 & 22 \\
Clades 2, 3 and other & Cold & 12 & 11 \\
& Warm & 0 & 3 \\
\hline
\end{tabular}

provisioned which may enhance early survivorship. There is no consistent relationship between oocyte size and either sexuality or mode of reproduction among the species in the data set (ANOVA; sexuality, $p=0.788$; mode of reproduction, $p=0.140$; interaction, $p=0.173)$. There was a significant relationship between oocyte size and subclade $(p=0.044)$ and a subclade by habitat interaction $(p=0.016)$, indicating that size varied between subclades and the effect was greater in some habitats than others. In some subclades, the trend was for larger oocytes in the subtropical and tropical habitats. However, these tests have low statistical power as there were few clades (for which data on oocyte sizes were available) with taxa in more than 2 habitats and no clade was represented in all 4 habitats.

Species with prolonged oogenesis lasting $>1 \mathrm{yr}$ have substantially larger oocytes than species with shorter oogenesis lasting $1 \mathrm{yr}$ or less (ANOVA, $\mathrm{p}=$ 0.013). Several octocoral species harbor an inventory of immature oocytes year-round with a fraction maturing during a seasonal oogenic cycle (e.g. Acabaria biserialis, Eunicella singularis, Tripalea clavaria) (Ben-Yosef \& Benayahu 1999, Excoffon et al. 2004, Ribes et al. 2007). This pattern is consistent with the theory that oogenesis is more energetically expensive than spermatogenesis. However, other species appear capable of creating large oocytes in $<1$ yr (e.g. Briareum asbestinum, Heliopora coerulea, Lobophytum pauciflorum) (Babcock 1990, Brazeau \& Lasker 1990, Fan et al. 2005).

Zooxanthellate species have significantly larger oocytes than azooxanthellate species (ANOVA, p < 0.001). Assuming oocyte size is correlated with energetic content, this relationship implies that the symbiosis with photosynthetic microalgae aids in the provisioning of oocytes.

\section{Reproductive effort (polyp fecundity)}

For sessile invertebrates where mating effort and parental care are minimal, reproductive output provides a good proxy for reproductive effort (Leuzinger et al. 2003). Polyp fecundity (i.e. number of mature oocytes per polyp) has often been used as an index of reproductive output. Polyp fecundity does not provide a complete measure of reproductive effort as it does not account for differences in the size and energetic value of oocytes, number of reproductive cycles per year, or differences in the size and density of the polyps on the colony (Harrison \& Wallace 1990). However, polyp fecundity is one of the few indices of 
reproductive effort that is widely reported, and if interpreted cautiously provides an approximation of reproductive effort. Polyp fecundity in octocorals varies widely (see Table S1). For the 58 species with polyp fecundity reported, there were significant differences between taxa whether analyzed as families or as subclades (ANOVA, p $<0.001)$, suggesting potential constraints associated with morphological features. In general, fleshy soft corals (sub-ordinal groups Stolonifera and Alcyoniina) exhibit much higher polyp fecundity than most sea fans and sea whips, which undoubtedly reflects the extension of the gastrovascular cavities in the fleshy species.

Octocoral polyp fecundity is not associated with length of oogenesis or symbiont status (i.e. zooxanthellate vs. azooxanthellate). Warm-water (tropical and subtropical) species had higher polyp fecundity than cold-water (cold or deep and temperate) species (ANOVA, $\mathrm{p}=0.046$ ). However, this pattern may also be a reflection of the relative absence of Alcyoniina in the deepwater faunas. Polyp fecundity data were available for relatively few hermaphroditic species, and there was a trend, albeit not significant, for those species to have higher polyp fecundity than gonochoric species (ANOVA, $\mathrm{p}=0.054$ ).

\section{Reproductive cycle/breeding}

Those octocorals for which there are data are iteroparous, and most species breed on an annual cycle after attaining a minimum size of sexual maturity. The data do not suggest any clear patterns. In general, the timing characteristics for broadcast spawning and brooding octocorals follow similar patterns as those of scleractinians in the same location. On the Great Barrier Reef in Australia, many octocorals and scleractinians exhibit short, seasonal, synchronized spawning episodes that coincide with the multispecies, synchronized, mass spawning events (Alino \& Coll 1989, Benayahu et al. 1990, Harrison \& Wallace 1990, Harrison 2011). Similarly, multi-species synchronous spawning events have been reported for Caribbean species (Coma \& Lasker 1997, Kapela \& Lasker 1999). At Eilat in the northern Red Sea, both zooxanthellate octocorals and scleractinians exhibit temporal reproductive isolation with synchronous spawning occurring on different dates or phases of the moon (Shlesinger \& Loya 1985, Benayahu et al. 1990). However, recent data indicate highly synchronous gamete maturation for acroporids in the Egyptian Red Sea (Hanafy et al. 2010). For intra-specific comparisons across a latitudinal gradient, a longer exposure to warm water has been positively correlated with a longer breeding season (Oliver et al. 1988, Mangubhai \& Harrison 2009, de Putron \& Ryland 2009).

Among broadcast spawning octocorals, continuous gametogenesis and year-round breeding has been reported in Dendronephthya hemprichi, Pennatula aculeata, and Carijoa riisei (Dahan \& Benayahu 1997, Eckelbarger et al. 1998, Kahng et al. 2008). A prolonged spawning season has also been reported in the zooxanthellate species Leptogorgia virgulata and Lobophytum crassum (Adams 1980, Fan et al. 2005). Highly variable reports on spawning by the Caribbean gorgoniids Pseudopterogia acerosa and P. americana (Yoshioka 1979, Bastidas et al. 2005) suggest that these broadcast spawners exhibit yearround or near year-round breeding. Although there has been tremendous attention to the multispecific, synchronous spawning events observed among some scleractinians in some locations, spawning patterns among scleractinians vary within and among species and across regions, and in some cases is neither as synchronous nor as temporally restricted as previously believed (Baird et al. 2009, Harrison 2011). Similar cases of 'fuzzy' synchrony are likely to occur among the octocorals.

For internal brooders, short breeding periods with synchronized planula release have been reported in Thrombophyton coronatum, Acabaria erythraea and Pseudopterogorgia hystrix (McFadden \& Hochberg 2003, Fine et al. 2005). Several external brooders also exhibit compressed breeding periods with synchronized planula release (e.g. Briareum hamra, $B$. asbestinum, Heliopora coerulea, Pseudopterogorgia bipinnata, P. elisabethae) (Benayahu 1989, Brazeau \& Lasker 1990, Harii \& Kayanne 2003, GutierrezRodriguez \& Lasker 2004). Azooxanthellate octocorals have longer breeding seasons than zooxanthellate octocorals (ANOVA, $p=0.038$ ). Deep water octocorals exhibit both short seasonal breeding periods (e. g. Thouarella variabilis, Corallium secundum, Ainigmaptilon antarcticum) and continuous, year-round breeding (Anthomastus ritteri, Pennatula aculeata) (Brito 1993, Eckelbarger et al. 1998, Cordes et al. 2001, Orejas et al. 2002, Waller \& Baco 2007).

\section{DISCUSSION}

While the phylogenetic relationships among anthozoan subgroups have been subject to changes in recent years, the subclass Octocorallia is widely accepted as a monophyletic clade within Anthozoa 
(Berntson et al. 1999, Fautin \& Romano 2000; Daly et al. 2003, Medina et al. 2006, Fukami et al. 2008). Grasshoff (1987) argues that both the octocorals and the hexacorals (which include the scleractinians) shared ancestry with a primitive anthozoan during the early Triassic. Given their shared ancestry and habitat, especially on tropical reefs, similarities in reproductive traits between alcyonacean and scleractinian corals could be expected. Instead, the 2 groups exhibit large differences.

Most striking of the differences between the 2 taxa is that octocorals are predominantly gonochoric $(89 \%$ of species) while scleractinians are predominantly hermaphrodites (71\%, Harrison 2011). Most clonal animals and plants are simultaneous hermaphrodites (Ghiselin 1974, Hall \& Hughes 1996). Scleractinian corals appear to fit this general pattern, but the rareness of hermaphroditism among alcyonacean corals does not have a simple explanation. The presence of simultaneous hermaphrodites in otherwise gonochoric species as well as species with differing sexuality in different regions in both scleractinians (Harrison 2011) and alcyonaceans (this review) suggests that an underlying capacity for hermaphroditic or mixed sexuality exists in some species. Thus, the difference between the 2 taxa cannot be attributed to taxonomically conserved sexuality.

Unlike the scleractinians where large clades are generally hermaphroditic (Kerr et al. 2011, but see Harrison 2011 for some exceptions), hermaphroditism among octocorals is scattered randomly across the octocoral clades and subclades. This suggests either a lack of transitions to hermaphroditism early in the history of octocorals, the failure of those transitions to persist, or higher rates of species origination among hermaphroditic scleractinians than among hermaphroditic octocorals. Although the outcome in numbers of species differs, seemingly both groups have undergone relatively few transitions from the ancestral gonochoric state. This suggests that the difference between scleractinians and octocorals can be attributed to the persistence of the trait and diversification among hermaphroditic scleractinian lineages. More complete sampling within the octocoral subclades as well as a robust phylogeny on which to map traits are both essential to addressing the processes responsible for the dramatically different pattern of sexuality of the 2 groups.

Octocorals again differ from scleractinians in the relative frequencies of the differing modes of reproduction. Harrison (2011) reports $82 \%$ of scleractinian coral species are broadcast spawners, $14 \%$ are internal brooders, and $3 \%$ exhibit both spawning and brooding in different locations. External brooding is not reported within Scleractinia; however, 1 species (Goniastrea favulus) retains eggs on the colony surface in a mucus envelope (Kojis \& Quinn 1981, Babcock 1984). This pattern is in marked contrast with the octocorals where only $49 \%$ of the species in the overall dataset broadcast spawn.

The overall pattern in sexuality and reproductive mode observed in the Scleractinia is one in which species are predominately hermaphroditic spawners (64\%) with a small but disproportionately large number of gonochoric brooders (4\%) (Baird et al. 2009, Harrison 2011). In contrast, the octocorals, particularly tropical species are most commonly gonochoric broadcast spawners (Table 6). When only sexuality and reproductive mode were considered for octocorals in a 2-way test of independence there was a significant association between traits (all species, $\mathrm{p}=0.006$ ), with an overrepresentation of gonochoric spawning species, gonochoric surface brooders and hermaphroditic brooding species. That pattern persists if climate (Table 4C), or climate and clade (analysis not shown) or subclade (Table 4D) are also included in a log-linear analysis. Table 4E also presents the results of log-linear analysis in which cli-

Table 6 . Sexuality and mode of reproduction from 182 octocoral species

\begin{tabular}{|c|c|c|c|c|c|c|c|}
\hline \multirow{2}{*}{$\begin{array}{l}\text { Mode of } \\
\text { reproduction }\end{array}$} & \multirow[b]{2}{*}{ Gonochoric } & \multirow[b]{2}{*}{$\begin{array}{c}\text { Gonochoric } \\
\text { with rare } \\
\text { herma- } \\
\text { phroditism }\end{array}$} & \multirow{2}{*}{$\begin{array}{l}\text { Sexu } \\
\text { Mixed or } \\
\text { contrasting } \\
\text { sexuality } \\
\text { reported }\end{array}$} & \multirow{2}{*}{$\begin{array}{l}\text { ty } \\
\text { Herma- } \\
\text { phroditic }\end{array}$} & \multirow[b]{2}{*}{$\begin{array}{l}\text { Partheno- } \\
\text { genetic }\end{array}$} & \multirow[b]{2}{*}{ Unknown } & \multirow{2}{*}{$\begin{array}{c}\text { Total } \\
\text { species }\end{array}$} \\
\hline & & & & & & & \\
\hline Spawning & 60 & 2 & 1 & 3 & & 8 & 74 \\
\hline Internal brooding & 37 & 5 & 2 & 7 & 1 & 11 & 63 \\
\hline External brooding & 14 & 2 & & & & 1 & 17 \\
\hline Contrasting mode reported & & & & 1 & & & 1 \\
\hline Unknown & 22 & & & 3 & & 2 & 27 \\
\hline Total species & 133 & 9 & 3 & 14 & 1 & 22 & 182 \\
\hline
\end{tabular}


mate, subclade, sexuality and mode of reproduction are simultaneously considered. The analysis is compromised by the number of cells with expected values below 5, but as in all of the other analyses sexuality and mode of reproduction are not independent. The relationship between sexuality and mode of reproduction disappears when the analysis is restricted to Clade 1 tropical species (Fisher's exact test, $p=0.08$ ) reflecting the relationships between climate, subclade and mode of reproduction. Polyp fecundity and maximum oocyte diameter did not vary with mode of reproduction. Those traits did, however, vary between clades and subclades, suggesting that history was more important in shaping those traits than selection on a specific reproductive strategy.

Are reproductive strategies among octocorals fundamentally different from scleractinians? The abundances of species in the different classes of reproductive strategy suggest a difference, but much of that pattern can be attributed to dominance of the genus Acropora in the scleractinian data. When only clades are considered in the data set of Baird et al. (2009), there is no significant association between hermaphroditism and broadcast spawning. Our analysis used the clade designations in the Baird et al. (2009) supplemental data $(\mathrm{G}=0.652, \mathrm{df}=1, \mathrm{p}=0.42)$. When taxa with mixed sexuality or reproductive mode were included or excluded, the results did not change. Kerr et al. (2011) have conducted a phylogenetic based analysis of transitions between the different character states and concluded that gonochorism among the Scleractinia has been 100 times more likely to be lost than hermaphroditism, and that among hermaphroditic species transitions to broadcast spawning are more likely than those to brooding. This suggests that much of the difference between octocorals and scleractinians has been a paucity of transitions from the presumed ancestral state of gonochorism among the octocorals. Mapping such transitions on the phylogenetic hypotheses of McFadden et al. (2006) suggests most such transitions have been closer to the twigs of the tree, but a more complete analysis will have to await the development of a more robust phylogeny.

\section{External brooding}

Although not a common mode of reproduction, external brooding occurs in both encrusting and arborescent growth forms in octocorals. Benayahu (1997) suggested that external surface brooding enables higher reproductive success than internal brooding by freeing gastrovascular cavity space for oocyte development. As in internal brooding, developing embryos or larvae of surface brooders have the potential of spending less time in the water column prior to settlement. Benayahu (1997) suggested that surface brooding could enhance larval survival compared to planktonic development. Shorter time in the water column (i.e. pelagic larval duration) could lead to more local dispersal (but see Weersing \& Toonen 2009), a trait that Szmant (1986) considered a key feature of brooding. Interestingly, the larvae of the Caribbean gorgoniids, Pseudopterogorgia elisabethae and P. bipinnata (Gutierrez-Rodriguez \& Lasker $2004 ;$ H. R. Lasker pers. obs.) are negatively buoyant, which should further promote limited dispersal. External brooding is associated with both internal and external fertilization (Benayahu et al. 1989) and may represent an evolutionary link between spawning and internal brooding.

While limiting time in the water column may reduce predation risk, the advantages associated with fertilization on the colony surface or within the polyps may underlie this reproductive strategy. In free-spawning marine organisms, extreme dilution of sperm to levels that limit fertilization (Denny \& Shibata 1989) can exert extremely strong selective pressure on reproductive strategies to maximize reproductive success (Oliver \& Babcock 1992, Levitan 1995, Levitan \& Petersen 1995, Yund 2000). For sessile marine invertebrates these strategies include spawning synchrony during times of low water motion, non-neutrally buoyant gametes, self-compatibility in hermaphrodites, and sperm concentrating mechanisms for enhancing internal fertilization (Denny \& Shibata 1989, Levitan 1991, 1996, Phillippi et al. 2004). Given the very limited period of viability of spawned coral eggs in the water column (e.g. Heyward \& Babcock 1986), retaining mature oocytes in the polyp cavity may provide a mechanism for lengthening the viability period for eggs and for increasing fertilization success through time, thus countering potential sperm limitation. Because isotropic turbulence increases the rate of contact between passively entrained particles with a spatially fixed surface (Denny \& Shibata 1989), spatially fixing the location of mature oocytes could increase their likelihood of contact with freely spawned sperm and help counter low concentration of sperm in the water column. For instance, Lasker (2006) found high fertilization rates among eggs retained on the surface of Pseudopterogorgia elisabethae colonies, and Yund \& Meidel (2003) suggested that even in broadcast spawning sea urchins much of the fertilizations may 
occur on the surface of the urchin, before eggs are advected away.

Surface brooding is absent in scleractinians, but 'quick release' or 'pseudo-brooding,' the immediate release of embryos following internal fertilization, has been reported in several scleractinians. This mode may represent an intermediate evolutionary link between broadcast spawning and internal brooding (de Graaf et al. 1999, Vermeij \& Bak 2003, Vermeij et al. 2004). Similar to external brooding, this mode of reproduction would both enhance fertilization success and help corals with small polyp size combine brooding with high fecundity by freeing polyp cavity space for developing oocytes and feeding. Evidence suggests this mode of reproduction may apply to some species reported as gonochoric, broadcast spawners. Internal fertilization has been reported in the broadcast spawning scleractinians Montastrea cavernosa and Stephanocoenia intersepta (Hagman et al. 1998), and both internal and external fertilization occur in Goniastrea aspera from Japan (Sakai 1997, Nozawa \& Harrison 2005). High viability of prematurely released embryos has been reported in internal brooding scleractinian Agaricia humilis (Petersen \& Van Moorsel 2005) suggesting that a prolonged internal brooding period is not a prerequisite for brooders. Additional coral species reported in the literature have features consistent with internal brooding (e.g. continuous, asynchronous gametogenesis in Carijoa riisei) but lack confirmation of embryos or planula within polyps (Kahng et al. 2008). For these corals, spawning is often assumed but internal fertilization followed by quick release can also be consistent with these observations.

Although uncommon in octocorals, the virtual absence of surface brooding among scleractinians is striking and the difference between the groups may relate to antipredator defenses. Scleractinians have hard aragonite skeletons that deter many predators, but most octocorals only have internal sclerites which are insufficient to deter generalist predators $\left(\mathrm{O}^{\prime} \mathrm{Neal}\right.$ \& Pawlik 2002); however, octocorals produce a diverse suite of chemical compounds that deter generalist predators (Coll et al. 1982, Coll 1992, Sammarco \& Coll 1992, Sammarco 1996). Externally brooded larvae forgo the protection afforded within a polyp, and eggs and larvae coating a colony surface are visually striking. The relatively large size of most octocoral oocytes would increase their visual detection distance and would seemingly provide an excellent food source for a wide variety of grazers and small predators. Chemical analysis of octocoral lar- vae has shown that the larvae, like the rest of the colony, are heavily defended with secondary metabolites that deter predation (Coll 1992, Sammarco \& Coll 1992, Kelman et al. 1999). Similarly, Lindquist \& Hay (1996) demonstrated that, among Caribbean sea fans, brooded larvae are more likely to be unpalatable to co-occurring fishes (100\% of 3 species) than larvae of broadcast spawners (33\% of 6 species). However, brooded larvae of the scleractinians that were tested (Agaricia agaricites, Porites asteroids, Siderastrea radians) were readily consumed and presumably undefended chemically (Lindquist \& Hay 1996). The hermatypic octocoral Heliopora coerulea is an external brooder (Babcock 1990, Harii et al. 2002), which suggests that external brooding is compatible with massive aragonite skeletons associated with scleractinians.

\section{Patterns of coral reef biodiversity}

In the Indo-Pacific, shallow-water coral reef flora and fauna exhibit well defined gradients of decreasing taxonomic diversity with distance away from the Indonesian Archipelago and the 'Coral Triangle' (Veron 1995, Paulay 1997, Burke et al. 2001, Spalding et al. 2003). Within the Coral Triangle, shallowwater scleractinians and octocorals are believed to exhibit similar levels of species richness ( 900 extant species) (Harrison 2011, P. Alderslade pers. comm.). However, in the most isolated regions of the IndoPacific (i.e. Hawaii and Eastern Pacific), the warmwater octocoral fauna is anomalously depauperate when compared to scleractinians (Grigg \& Bayer 1976, Paulay 1997). For example, compared to the center of the Indonesian Archipelago, Hawaii has $\sim 10 \%$ the species richness of shallow-water scleractinian corals yet $<1 \%$ of the estimated species richness of shallow-water octocorals (Devaney \& Eldredge 1977, Maragos 1995, Veron 2000, Fenner 2005).

In the Gulf of Mexico, Jordan-Dalgren (2002) found a similar decreasing gradient of species richness for both shallow-water octocorals and scleractinians from the tip of the Yucatan peninsula clockwise (down current) to the Flower Garden Banks. The relative decline in species richness is much greater for octocorals than scleractinians (Rezak et al. 1985, Veron 1995, Jordan-Dalgren 2002).

These differences suggest a differential capability to disperse to remote locations or a differential capability to persist in these locations over ecological timescales. However, the reproductive traits of shal- 
low-water scleractinians compared to their octocoral counterparts do not reveal any obvious patterns which would facilitate greater dispersal capabilities by scleractinian corals. While speculative, one possible explanation may be that reef scleractinians are less prone to extirpation than reef octocorals. Some scleractinian colonies are known to live for several centuries (Soong et al. 1999). Some evidence suggests that zooxanthellate scleractinians may be able to utilize a wider range of habitats than zooxanthellate octocorals including a greater depth range, areas of higher wave energy, and possibly areas of lower water quality (Dai 1991, Fabricius et al. 2005, Kahng et al. 2010). Greater habitat area available for reef scleractinians versus octocorals may facilitate the maintenance of greater biodiversity in more isolated locations (Bellwood \& Hughes 2001).

Acknowledgements. Special thanks to the following octocoral researchers who provided the authors with unpublished information and manuscripts on octocoral species over the past 6 years: P. Alderslade, T. Brito, T. Chang, C. Dai, M. C. Ferreira, M. Fine, J. Duncan Forrester, M. Gawel, S. Harii, M. Janes, C. Linares, C. McFadden, A. Mercier, N. Rothe, M. Schleyer, J. I. Song, Z. Sun, K. Soong, P. Tyler, B. Velimirov, O. O. Vicente, R. Waller, and M. Weinbauer. Thanks to B. Li for translating Chinese octocoral manuscripts and the staff of the Interuniversity Institute for Marine Sciences of Eilat. This research was financially supported in part by the Hawaii Pacific University (HPU) Trustees' Scholarly Endeavors Program; the Israel Cohen Chair in Environmental Zoology at Tel Aviv University; and US National Science Foundation grants 0327129 and 0825852 .

\section{LITERATURE CITED}

Achituv Y, Benayahu Y (1990) Polyp dimorphism and functional, sequential hermaphroditism in the soft coral Heteroxenia fuscescens (Octocorallia). Mar Ecol Prog Ser 64:263-269

Adams RO (1980) Investigations of color, morphology and development of the sea whip, Leptogorgia virgulata, (Lamarck) (Cnidaria: Octocorallia: Gorgonacea). PhD thesis, Florida State University

Alderslade P (2001) Six new genera and six new species of soft coral, and some proposed familial and subfamilial changes within the Alcyonacea (Coelenterata: Octocorallia). Bull Biol Soc Wash 10:15-65

Alino PM, Coll JC (1989) Observations of the synchronized mass spawning and post settlement activity of octocorals on the Great Barrier Reef, Australia: biological aspects. Bull Mar Sci 45:697-707

Babcock RC (1984) Reproduction and distribution of two species of Goniastrea (Scleractinia) from the Great Barrier Reef Province. Coral Reefs 2:187-195

Babcock RC (1990) Reproduction and development of the blue coral Heliopora coerulea (Alcyonaria: Coenothecalia). Mar Biol 104:475-481
Baird AH, Guest JR, Willis BL (2009) Systematic and biogeographical patterns in the reproductive biology of scleractinian corals. Annu Rev Ecol Evol Syst 40:551-571

Bastidas C, Croquer A, Zubillaga AL, Ramos R, Kortnik V, Weinberger C, Marquez LM (2005) Coral mass- and split-spawning at a coastal and an offshore Venezuelan reefs, southern Caribbean. Hydrobiologia 541:101-106

Bayer FM (1961) The shallow-water Octocorallia of the West Indian region: A manual for marine biologists. Martinus Nijhoff, The Hague

Bayer FM (1981) Status of knowledge of octocorals of world seas. Seminários de biologia marinha, Academia Brasileira de Ciências, Rio de Janeiro, p 3-11

Bellwood DR, Hughes TP (2001) Regional-scale assembly rules and biodiversity of coral reefs. Science 292: 1532-1535

Ben-Yosef DZ, Benayahu Y (1999) The gorgonian coral Acabaria biserialis: Life history of a successful colonizer of artificial substrata. Mar Ecol Prog Ser 163:235-243

> Benayahu Y (1989) Reproductive cycle and developmental processes during embryogenesis of Clavularia hamra (Cnidaria, Octocorallia). Acta Zool 70:29-36

- Benayahu Y (1991) Reproduction and developmental pathways of Red Sea Xeniidae (Octocorallia, Alcyonacea). Hydrobiologia 216-217:125-130

Benayahu Y (1997) Developmental episodes in reef soft corals: Ecological and cellular determinants. Proc 8th Int Coral Reef Symp 2:1213-1218

Benayahu Y, Loya Y (1981) Competition for space among coral-reef sessile organisms at Eilat, Red Sea. Bull Mar Sci 31:514-522

> Benayahu Y, Loya Y (1983) Surface brooding in the Red Sea soft coral Parerythropodium fulvum fulvum (Forskal, 1775). Biol Bull 165:353-369

Benayahu Y, Loya Y (1984) Life history studies on the Red Sea soft coral Xenia macrospiculata Gohar, 1940. I. Annual dynamics of gonadal development. Biol Bull 166: 32-43

Benayahu Y, Loya Y (1986) Sexual reproduction of a soft coral: Synchronous and brief annual spawning of Sarcophyton glaucum (Quoy \& Gaimard, 1833). Biol Bull 170: 32-42

> Benayahu Y, Berner T, Achituv Y (1989) Development of planulae within a mesogleal coat in the soft coral Heteroxenia fuscescens. Mar Biol 100:203-210

Benayahu Y, Weil D, Kleinman M (1990) Radiation of broadcasting and brooding patterns in coral reef alcyonanceans. In: Hoshi $M$, Yamashita $O$ (eds) Advances in invertebrate reproduction 5. Elsevier, Amsterdam, p 323-328

Benayahu Y, Weil D, Malik Z (1992) Entry of algal symbionts into oocytes of the coral Litophyton arboreum. Tissue Cell 24:473-482

Berntson EA, France SC, Mullineaux LS (1999) Phylogenetic relationships within the class Anthozoa (Phylum Cnidaria) based on nuclear 18S rDNA sequences. Mol Phylogenet Evol 13:417-433

> Berntson EA, Bayer FM, McArthur AG, France SC (2001) Phylogenetic relationships within the Octocorallia (Cnidaria: Anthozoa) based on nuclear 18S rRNA sequences. Mar Biol 138:235-246

Bock S (1938) The alcyonarian genus Bathyalcyon. K Sven Vetenskapsakad Handl (Tredje Serien) 14:1-54

Brazeau DA (1989) A male-biased sex ratio in the Caribbean octocoral, Briareum asbestinum: Sex ratio evolution in 
clonal organisms. PhD thesis, State University of New York at Buffalo

Brazeau DA, Lasker HR (1989) The reproductive cycle and spawning in a Caribbean gorgonian. Biol Bull 176:1-7 (Woods Hole)

Brazeau DA, Lasker HR (1990) Sexual reproduction and external brooding by the Caribbean gorgonian Briareum asbestinum. Mar Biol 104:465-474

Brito TAS (1993) Taxonomic and ecological studies on Antarctic octocorals of the genus Thouarella (Octocorallia, Primoidae). PhD thesis, University of Southampton

Burke L, Kura Y, Kassem K, Revenga C, Spalding M, McAllister D, Caddy J (2001) Coastal ecosystems. Report No. 1-56973-458-5, World Resources Institute

Chang TC (2007) Sexual reproduction of four gorgonian corals in southern Taiwan. MSc thesis, National Sun Yetsen University, Taiwan, p46

Chou YH (2002) Sexual reproduction of three alcyonacean species in southern Taiwan. MSc thesis, National Taiwan University

Coffroth MA, Lasker HR (1998) Larval paternity and male reproductive success of a broadcast-spawning gorgonian, Plexaura kuna. Mar Biol 131:329-337

Coll JC (1992) The chemistry and chemical ecology of octocorals (Coelenterata, Anthozoa, Octocorallia. Chem Rev 92:613-631

Coll J, La Barre S, Sammarco P, Williams WT, Bakus GJ (1982) Chemical defenses in soft corals (Coelenterata: Octocorallia) of the Great Barrier Reef: A study of comparative toxicities. Mar Ecol Prog Ser 8:271-278

Coma R, Lasker HR (1997) Small-scale heterogeneity of fertilization success in a broadcast spawning octocoral. J Exp Mar Biol Ecol 214:107-120

Concepcion GT, Kahng SE, Crepeau MW, Franklin EC, Coles SL, Toonen RJ (2010) Resolving natural ranges and marine invasions in a globally distributed octocoral (genus Carijoa). Mar Ecol Prog Ser 401:113-127

> Cordes EE, Nybakken JW, VanDykhuizen G (2001) Reproduction and growth of Anthomastus ritteri (Octocorallia: Alcyonacea) from Monterey Bay, California, USA. Mar Biol 138:491-501

> Dahan M, Benayahu Y (1997) Reproduction of Dendronephythya hemprichi (Cnidaria: Octocorallia): Year-round spawning in an azooxanthellate soft coral. Mar Biol 129: 573-579

- Dai CF (1991) Distribution and adaptive strategies of alcyonacean corals in Nanwan Bay, Taiwan. Hydrobiologia 216-217:241-246

Daly M, Fautin DG, Cappola VA (2003) Systematics of the Hexacorallia (Cnidaria: Anthozoa). Zool J Linn Soc 139: 419-437

Danielssen DC, Koren J (1884) Pennatulida. Den Norske Nordhavs-Expedition, 1876-1878. Zoologi 12

Davis SA (1977) Some aspects of the biology of Anthelia edmondsoni (Verrill). MSc thesis, University of Hawaii, Honolulu, HI

de Graaf M, Geertjes GJ, Videler JJ (1999) Observations on spawning of scleractinian corals and other invertebrates on the reefs of Bonaire (Netherlands Antilles Caribbean). Bull Mar Sci 64:189-194

de Lacaze-Duthiers H (1864) Histoire naturelle du corail: Organisation-reproduction-pêche en Algérie-industrie et commerce. J.B. Baillière et Fils, Paris

de Lacaze-Duthiers H (1900) Coralliaires du Golfe du Lion: Alcyonaires. Arch Zool Exp Gen 3:353-462 de Putron SJ, Ryland JS (2009) Effect of seawater temperature on reproductive seasonality and fecundity of Pseudoplexaura porosa (Cnidaria: Octocorallia): Latitudinal variation in Caribbean gorgonian reproduction. Invertebr Biol 128:213-222

Denny MW, Shibata MF (1989) Consequences of surf-zone turbulence for settlement and external fertilization. Am Nat 134:859-889

Devaney DM, Eldredge LG (1977) Reef and shore fauna of Hawaii section 1: Protozoa through Ctenophora, Vol 64(1). Bishop Museum, Honolulu, HI

$>$ Dinesen ZD (1983) Patterns in the distribution of soft corals across the central Great Barrier Reef. Coral Reefs 1: $229-236$

> Eckelbarger KJ, Tyler PA, Langton RW (1998) Gonadal morphology and gametogenesis in the sea pen Pennatula aculeata (Anthozoa: Pennatulacea) from the Gulf of Maine. Mar Biol 132:677-690

Excoffon AC, Acuna FH, Zamponi MO, Genzano GN (2004) Reproduction of the temperate octocoral Tripalea clavaria (Octocorallia: Anthothelidae) from sublittoral outcrops off Mar del Plata, Argentina. J Mar Biol Assoc UK 84:695-699

Fabricius KE, Alderslade P (2001) Soft corals and sea fans: A comprehensive guide to the tropical shallow-water genera of the Central-West Pacific, the Indian Ocean, and the Red Sea. Australian Institute of Marine Science, Townsville MC

Fabricius K, De'ath G, McCook L, Turak E, Williams DMB (2005) Changes in algal, coral and fish assemblages along water quality gradients on the inshore Great Barrier Reef. Mar Pollut Bull 51:384-398

> Fadlallah YH (1983) Sexual reproduction, development and larval biology in scleractinian corals. Coral Reefs 2: 129-150

Fan TY, Chou YH, Dai CF (2005) Sexual reproduction of the alcyonacean coral Lobophytum pauciflorum in southern Taiwan. Bull Mar Sci 76:143-154

Farrant PA (1986) Gonad development and the planulae of the temperate Australian soft coral Capnella gaboensis. Mar Biol 92:381-392

Fautin DG, Romano SL (2000) Anthozoa. Sea anemones, corals, sea pens. Version 03 October 2000. http://tolweb. org/anthozoa/17634/2000.10.03 in The Tree of Life Web Project, http://tolweb.org/

Fenner D (2005) Corals of Hawai'i. A field guide to the hard, black, and soft corals of Hawai'i and the Northwest Hawaiian Islands including Midway. Mutual Publishing, Honolulu

Fine M, Aluma Y, Meroz-Fine E, Abelson A, Loya Y (2005) Acabaria erythraea (Octocorallia: Gorgonacea) a successful invader to the Mediterranean Sea? Coral Reefs 24:161-164

Fukami H, Chen CA, Budd AF, Collins A, and others (2008) Mitochondrial and nuclear genes suggest that stony corals are monophyletic but most families of stony corals are not (Order Scleractinia, Class Anthozoa, Phylum Cnidaria). PLoS ONE 3:e3222

Ghiselin MT (1974) The economy of nature and the evolution of sex. University of California Press, Berkeley, CA

Gohar HAF (1940a) The development of some Xeniidae (Alcyonaria) (with some ecological aspects). Publ Mar Biol Stn Ghardaqa 3:27-70

Gohar HAF (1940b) Studies on the Xeniidae of the Red Sea. Publ Mar Biol Stn Ghardaqa 2:27-118 
Gohar HAF, Roushdy HM (1961) On the embryology of the Xeniidae (Alcyonaria) (with notes on the extrusion of the larvae). Publ Mar Biol Stn Ghardaqa 11:45-70

Grasshoff M (1987) Cnidarian phylogeny - a biomechanical approach. Palaeontogr Am 117:127-135

Grigg RW, Bayer FM (1976) Present knowledge of the systematics and zoogeography of the order Gorgonacea in Hawaii. Pac Sci 30:167-175

Guinotte JM, Orr J, Cairns S, Freiwald A, Morgan L, George $R$ (2006) Will human-induced changes in seawater chemistry alter the distribution of deep-sea scleractinian corals? Front Ecol Environ 4:141-146

> Gutierrez-Rodriguez C, Lasker HR (2004) Reproductive biology, development, and planula behavior in the Caribbean gorgonian Pseudopterogorgia elisabethae. Invertebr Biol 123:54-67

Hagman DK, Gittings SR, Vize PD (1998) Fertilization in broadcast-spawning corals of the Flower Garden Banks National Marine Sanctuary. Gulf Mex Sci 16:180-187

Hall VR, Hughes T (1996) Reproductive strategies of modular organisms: Comparative studies of reef-building corals. Ecology 77:950-963

- Hanafy MH, Aamer MA, Habib M, Rouphael AB, Baird AH (2010) Synchronous reproduction of corals in the Red Sea. Coral Reefs 29:119-124

Harii S, Kayanne H (2003) Larval dispersal, recruitment, and adult distribution of the brooding stony octocoral Heliopora coerulea on Ishigaki Island, southwestern Japan. Coral Reefs 22:188-196

Harii S, Kayanne H, Takigawa H, Hayashibara T, Yamamoto M (2002) Larval survivorship, competency periods and settlement of two brooding corals, Heliopora coerulea and Pocillopora damicornis. Mar Biol 141:39-46

Harrison PL (2011) Sexual reproduction of scleractinian corals. In: Dubinsky Z, Stambler N (eds) Coral reefs: An ecosystem in transition. Springer, Dordrecht, p 59-85

Harrison PL, Wallace CC (1990) Reproduction, dispersal and recruitment of scleractinian corals. In: Dubinsky Z (ed) Ecosystems of the world, Vol 25: Coral reefs. Elsevier, New York, p 133-207

Hartnoll RG (1977) Reproductive strategy in two British species of Alcyonium. In: Keegan BF, Ceidigh PO, Boaden PJS (eds) Biology of benthic organisms. Pergamon Press, Oxford, p 321-328

Heyward AJ, Babcock RC (1986) Self- and cross-fertilization in scleractinian corals. Mar Biol 90:191-195

Hickson SJ (1895) The anatomy of Alcyonium digitatum. Q J Microsc Sci 37:343-348

Hickson SJ (1901) Liverpool marine biology committee memoirs on typical British marine plants \& animals, No. V. Alcyonium, Vol V. Williams and Norgate, London

Hickson SJ (1931) The alcyonarian family Xeniidae, with a revision of the genera and species. Great Barrier Reef Expedition 1928-29, IV 5:18-179

Hill MD, Oxon MA (1905) Notes on the maturation of the ovum of Alcyonium digitatum. Q J Microsc Sci 49: 493-505

Hinderstein LM, Marr JCA, Martinez FA, Dowgiallo MJ, and others (2010) Introduction to mesophotic coral ecosystems: characterization, ecology, and management. Coral Reefs 29:247-251

Hyman LH (1940) The invertebrates: Protozoa through Ctenophora, Vol 1. McGraw-Hill, New York, NY

Jackson JBC (1985) Distribution and ecology of clonal and aclonal benthic invertebrates. In: Jackson J, Buss L,
Cook R (eds) Population biology and evolution of clonal organisms. Yale University Press, New Haven, p 297-355

Jackson JBC (1986) Modes of dispersal of clonal benthic invertebrates: Consequences for species' distributions and genetic structure of local populations. Bull Mar Sci 32:588-606

Jordan-Dalgren E (2002) Gorgonian distribution patterns in coral reef environments of the Gulf of Mexico: Evidence of sporadic ecological connectivity? Coral Reefs 21: 205-215

Kahng SE, Benayahu Y, Wagner D, Rothe N (2008) Sexual reproduction in the invasive octocoral, Carijoa riisei (Duchassaing \& Michelotti, 1860), in Hawaii. Bull Mar Sci 82:1-17

Kahng SE, Garcia-Sais J, Spalding H, Brokovich E, and others (2010) Community ecology of mesophotic coral reef ecosystems. Coral Reefs 29:255-275

Kapela W, Lasker HR (1999) Size-dependent reproduction in the Caribbean gorgonian Pseudoplexaura porosa. Mar Biol 135:107-114

> Kelman D, Benayahu Y, Kashman Y (1999) Chemical defence of the soft coral Parerythropodium fulvum fulvum (Forskal) in the Red Sea against generalist reef fish. J Exp Mar Biol Ecol 238:127-137

Kerr AM, Baird AH, Hughes TP (2011) Correlated evolution of sex and reproductive mode in corals (Anthozoa: Scleractinia). Proc Biol Sci 278:75-81

Kojis BL, Quinn NJ (1981) Aspects of sexual reproduction and larval development in the shallow water hermatypic coral, Goniastrea australensis. Bull Mar Sci 31: 558-573

Kowalewsky A, Marion A (1883) Documents pour l'histoire embryogenique des Alcyonairs. Ann Mus Hist Nat Marseille 1:6-50

Lasker HR (1988) The incidence and rate of vegetative propagation among coral reef alcyonarians. Proc 6th Int Coral Reef Symp, Townsville 2:763-768

Lasker HR (2006) High fertilization success in a surfacebrooding Caribbean gorgonian. Biol Bull 210:10-17

Leuzinger S, Anthony KRN, Willis BL (2003) Reproductive energy investment in corals: Scaling with module size. Oecologia 136:524-531

Levitan DR (1991) Influence of body size and population density on fertilization success and reproductive output in a free-spawning invertebrate. Biol Bull 181:261-268

Levitan DR (1995) The ecology of fertilization in free-spawning invertebrates. In: McEdward L (ed) Ecology of marine invertebrate larvae, Vol 6. CRC Press, Boca Raton, FL, p 123-156

Levitan DR (1996) Effects of gamete traits on fertilization in the sea and the evolution of sexual dimorphism. Nature 382:153-155

Levitan DR, Petersen C (1995) Fertilization in the sea. Trends Ecol Evol 10:228-231

> Linares C, Coma R, Zabala M (2008) Effects of a mass mortality event on gorgonian reproduction. Coral Reefs 27: 27-34

Lindquist N, Hay ME (1996) Palatability and chemical defense of marine invertebrate larvae. Ecol Monogr 66: $431-450$

Loya Y, Sakai K (2008) Bidirectional sex change in mushroom stony corals. Proc Biol Sci 275:2335-2343

Loya Y, Sakai K, Heyward A (2009) Reproductive patterns of fungiid corals in Okinawa, Japan. Galaxea 11:119-129 
Lumsden SE, Hourigan TF, Bruckner AW, Dorr G (2007) The state of deep coral ecosystems of the United States. NOAA Technical Memorandum CRCP-3, Silver Spring, MD

> Mangubhai S, Harrison PL (2009) Extended breeding seasons and asynchronous spawning among equatorial reef corals in Kenya. Mar Ecol Prog Ser 374:305-310

Maragos JE (1995) Revised checklist of extant shallowwater stony coral species from Hawai'i (Cnidaria: Anthozoa: Scleractinia). Bishop Mus Occas Paper 42:54-55

Matthews A (1917) The development of Alcyonium digitatum with some notes on the early colony formation. Q J Microsc Sci 62:43-94

McFadden CS (1991) A comparative demographic analysis of clonal reproduction in a temperate soft coral. Ecology 72:1849-1866

McFadden CS (1997) Contributions of sexual and asexual reproduction to population structure in the clonal soft coral, Alcyonium rudyi. Evolution 51:112-126

> McFadden CS (2001) A molecular phylogenetic analysis of reproductive trait evolution in the soft coral genus Alcyonium. Evolution 55:54-67

> McFadden CS, Hochberg FG (2003) Biology and taxonomy of encrusting alcyoniid soft corals in the northeastern Pacific Ocean with descriptions of two new genera (Cnidaria, Anthozoa, Octocorallia). Invertebr Biol 122:93-113

McFadden CS, France SC, Sanchez JA, Alderslade P (2006) A molecular phylogenetic analysis of the Octocorallia (Cnidaria: Anthozoa) based on mitochondrial proteincoding sequences. Mol Phylogenet Evol 41:513-527

McFadden CS, Van Ofwegen LP, Beckman EJ, Benayahu Y, Alderslade P (2009) Molecular systematics of the speciose Indo-Pacific soft coral genus, Sinularia (Anthozoa: Octocorallia). Invertebr Biol 128:303-323

Medina M, Collins AG, Takaoka TL, Kuehl JV, Boore JL (2006) Naked corals: skeleton loss in Scleractinia. Proc Natl Acad Sci USA 103:9096-9100

> Mercier A, Hamel JF (2011) Contrasting reproductive strategies in three deep-sea octocorals from eastern Canada: Primnoa resedaeformis; Keratoisis ornata, and Anthomastus grandiflorus. Coral Reefs 30:337-350

Messing CG, Reed JK, Brooke SD, Ross SW (2008) Deepwater coral reefs of the United States. In: Riegl BM, Dodge RE (eds) Coral reefs of the USA. Springer, Berlin, p $767-792$

> Nozawa Y, Harrison PL (2005) Temporal settlement patterns of larvae of the broadcast spawning reef coral Favites chinensis and the broadcast spawning and brooding reef coral Goniastrea aspera from Okinawa, Japan. Coral Reefs 24:274-282

Nutting CC (1912) Descriptions of the Alcyonaria collected by the US Fisheries steamer 'Albatross,' mainly in Japanese waters, during 1906. Proc US Natl Mus 43:1-104

O'Neal W, Pawlik JR (2002) A reappraisal of the chemical and physical defenses of Carribean gorgonian corals against predatory fishes. Mar Ecol Prog Ser 240:117-126

Oliver JK, Babcock RC (1992) Aspects of the fertilization ecology of broadcast spawning corals: sperm dilution effects and in situ measurements of fertilization. Biol Bull 183:409-417

Oliver JK, Babcock RC, Harrison PL, Willis BL (1988) Geographic extent of mass coral spawning: clues to ultimate causal factors. Proc 6th Int Coral Reef Symp, Townsville, 2:803-810

Orejas C, Lopez-Gonzales PJ, Gili JM, Teixido N, Gutt J,
Arntz W (2002) Distribution and reproductive ecology of the Antarctic octocoral Ainigmaptilon antarcticum in the Weddell Sea. Mar Ecol Prog Ser 231:101-114

Paulay G (1997) Diversity and distribution of reef organisms. In: Birkeland C (ed) Life and death of coral reefs. Chapman \& Hall, New York, NY, p 298-353

> Petersen D, Van Moorsel G (2005) Pre-planular external development in the brooding coral Agaricia humilis. Mar Ecol Prog Ser 289:307-310

> Phillippi A, Hamann E, Yund PO (2004) Fertilization in an egg-brooding colonial ascidian does not vary with population density. Biol Bull 206:152-160

Pratt EM (1903) The Alcyonaria of the Maldives, Part II: The genera Sarcophytum, Lobophytum, Sclerophytum and Alcyonium. Fauna and Geography of the Maldive and Laccadive Archipelagoes 2:503-539

Rezak R, Bright TJ, McGrail DW (1985) Reefs and banks of the northwestern Gulf of Mexico: Their geological, biological, and physical dynamics. Wiley \& Sons, New York, NY

> Ribes M, Coma R, Rossi S, Micheli M (2007) Cycle of gonadal development in Eunicella singularis (Cnidaria: Octocorallia): trends in sexual reproduction in gorgonians. Invertebr Biol 126:307-317

Richmond R (1997) Reproduction and recruitment in corals: Critical links in the persistence of reefs. In: Birkeland C (ed) Life and death of coral reefs. Chapman \& Hall, New York, NY, p 175-197

> Richmond RH, Hunter CL (1990) Reproduction and recruitment of corals: Comparisons among the Caribbean, the tropical Pacific, and the Red Sea. Mar Ecol Prog Ser 60: 185-203

Sakai K (1997) Gametogenesis, spawning, and planula brooding by the reef coral Goniastrea aspera (Scleractinia) in Okinawa, Japan. Mar Ecol Prog Ser 151:67-72

Sammarco PW (1996) Comments on coral reef regeneration, bioerosion, biogeography, and chemical ecology: future directions. J Exp Mar Biol Ecol 200:135-168

Sammarco PW, Coll JC (1992) Chemical adaptations in the Octocorallia: Evolutionary considerations. Mar Ecol Prog Ser 88:93-104

Sanchez JA, McFadden C, France SC, Lasker H (2003) Molecular phylogenetic analyses of shallow-water Caribbean octocorals. Mar Biol 142:975-987

Schleyer MH, Kruger A, Benayahu Y (2004) Reproduction and the unusual condition of hermaphroditism in Sarcophyton glaucum (Octocorallia, Alyoniidae) in KwaZuluNatal, South Africa. Hydrobiologia 530-531:399-409

Shlesinger Y, Loya Y (1985) Coral community reproductive patterns: Red Sea versus GBR. Science 228:1333-1335

> Shlesinger Y, Goulet TL, Loya Y (1998) Reproductive patterns of scleractinian corals in the northern Red Sea. Mar Biol 132:691-701

Simpson A (2005) Reproductive morphology of two deep-water octocorals, Paramuricea placomus (Plexauridae) and Metallogorgia melanotrichos (Chrysogorgiidae). 3rd Int Symp Deep-Sea Corals. Rosenstiel School of Marine and Atmospheric Sciences, University of Miami, FL, p 203

Smith JM (1978) The evolution of sex. Cambridge University Press, Cambridge

> Soong K, Chen CA, Chang JC (1999) A very large poritid colony at Green Island, Taiwan. Coral Reefs 18:42

Spalding MD, Ravilious C, Green EP (2001) World atlas of coral reefs. University of California Press, Berkeley, CA

Spalding M, Taylor M, Ravilious C, Short F, Green E (2003) The distribution and status of seagrasses. In: Green E, 
Short F (eds) World atlas of seagrasses. University of California Press, Berkeley, CA, p 5-26

Sun Z, Hamel JF, Mercier A (2009) Planulation of deep-sea octocorals in the NW Atlantic. Coral Reefs 28:781

Sun Z, Hamel JF, Edinger E, Mercier A (2010) Reproductive biology of the deep-sea octocoral Drifa glomerata in the northwest Atlantic. Mar Biol 157:863-873

Szmant AM (1986) Reproductive ecology of Caribbean reef corals. Coral Reefs 5:43-54

Thorpe L (1928) Alcyonaria of the Abrolhos Islands, Western Australia. J Linn Soc Lond Zool 36:479-531

Tyler PA, Bronsdon SK, Young CM, Rice AL (1995) Ecology and gametogenic biology of the genus Umbellula (Pennatulacea) in the North Atlantic Ocean. Int Rev Gesamten Hydrobiol Hydrograph 80:187-199

Utinomi H, Imahara Y (1976) A new second species of dimorphic alcyonacean octocoral Minabea from the bays of Sagami and Suruga, with the emendation of generic diagnosis. Publ Seto Mar Biol Lab 23:205-212

Vermeij MJA, Bak RPM (2003) Species-specific population structure of closely related coral morphospecies along a depth gradient (5-60 m) over a Caribbean reef slope. Bull Mar Sci 73:725-744

Vermeij MJA, Sampayo E, Broker K, Bak R (2004) The reproductive biology of closely related coral species: gametogenesis in Madracis from the southern Caribbean. Coral Reefs 23:206-214

Vermeire MJ (1994) Reproduction and growth of a gorgonian sea whip, Junceella fragilis, in southern Taiwan. MSc

Editorial responsibility: Karen Miller,

Hobart, Tasmania, Australia thesis, National Taiwan University

Veron JEN (1995) Corals in time and space. University of South Wales Press, Sydney

Veron JEN (2000) Corals of the world. Australian Institute of Marine Science, Townsville

Waller RG, Baco AR (2007) Reproductive morphology of three species of deep-water precious corals from the Hawaiian Archipelago: Gerardia sp., Corallium secundum, and Corallium lauuense. Bull Mar Sci 81:533-542

Weersing K, Toonen RJ (2009) Population genetics, larval dispersal, and connectivity in marine systems. Mar Ecol Prog Ser 393:1-12

Yamazato K, Sato M, Tamashiro H (1981) Reproductive biology of an alcyonacean coral, Lobophytum crassum Marenzeller. Proc 4th Int Coral Reef Symp, Manila 2: 671-678

Yeung CW, Ang P (2008) Sexual reproduction in the soft coral Lobophytum sp. in Tung Ping Chau Marine Park, Hong Kong SAR, China. Proc 11th Int Coral Reef Symp, Ft. Landerdale, FL 1:378-381

Yoshioka BB (1979) Aspects of the ecology of Pseudopterogorgia americana and Pseudopterogorgia acerosa. MSc thesis, University of Puerto Rico, Mayaguez

Yund PO (2000) How severe is sperm limitation in natural populations of marine free-spawners? Trends Ecol Evol 15:10-13

> Yund PO, Meidel SK (2003) Sea urchin spawning in benthic boundary layers: Are eggs fertilized before advecting away from females? Limnol Oceanogr 48:795-801

Submitted: May 9, 2011; Accepted: September 22, 2011

Proofs received from author(s): December 2, 2011 